不連続炭素䋊維強化プラスチックによる新規な軽量フォーム材の作製 ${ }^{\dagger}$ 武部 佳樹* 平野 啓之* 本間 雅登*

篠原 光太郎* 藤岡 聖*

\title{
A New Foam Material Made from Discontinuous Carbon Fiber Reinforced Plastics
}

by

\author{
Yoshiki TAKEBE*, Noriyuki HIRANO*, Masato HONMA*, \\ Kotaro SHINOHARA* and Takashi FUJIOKA*
}

\begin{abstract}
Sandwich panels are widely used in building construction, housing and transportation equipment. The core is normally used low density material such as honeycomb structure or cell-structured thermoplastic foams. However, they have difficulties molding complex shaped structures and being weak in shear. A new stiff and lightweight carbon fiber reinforced foam (CFRF) was manufactured by focusing on spring back effect of monofilament dispersed discontinuous CFRTP (Carbon Fiber Reinforced Thermoplastic). Specific bending modulus of polypropylene matrix CFRF was changed from 2.20 to 5.30 depending on spring back ratio. Press molding for complex shaped CFRF including curved surface and deep drawing structures was successfully obtained by one-step procedure. Furthermore, sandwich structure having solid polyamide skin was also obtained in the same method.
\end{abstract}

\section{Key words:}

CFRTP, CFRF, Sandwich structures, Lightweight, Specific bending modulus, Foam core

\section{1 緒言}

サンドイッチ構造による構造体の軽量化技術は，ダン ボールやコンテナなどの梱包資材から建材, 航空機など の輸送機器に至るまで幅広く活用されている。一般にサ ンドイッチ構造では，スキンが曲げ荷重と面内負荷を支 え，コアがせん断荷重を受け持つ. 軽量のコアで重量増 加を抑えつつ十分な厚さを確保でき，全体の面外変形が 抑えられることから，特に比曲げ岡性に優れる.

しかし，サンドイッチ構造体を得るためには，スキン 材を配置した型内にコアを充填するか，先にコアを加工 して, スキンを貼り付ける工程が必要となる。これらは, 複雑形状への賦形時に量産性を損なうため問題となる.

さらに, サンドイッチ構造体の更なる性能向上を考え ると，フォームコア自体の弾性率向上も必要となる ${ }^{1)}$. そ こで, 強化繊維を活用した樹脂フォームの研究 ${ }^{2), 3)}$ フォームと強化繊維の組合せが検討されている。しかし， 型内充填で作製するため量産性に劣り，弾性率向上につ いは僅かである。さらに，アルミフォームのスキンとの

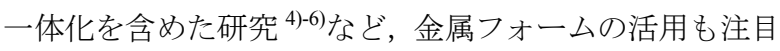
されている。しかし，金属フォームは加工温度などの問 題から，樹脂フォームのような汎用性はない。そこで筆 者らは, 軽量・高弾性率である炭素繊維強化複合材料

(CFRP) の，フォームとしての活用を考えた.
不連続の炭素繊維で強化された熱可塑性樹脂 (CFRTP) 材料では，成形時の樹脂の加熱溶融時に伴い，屈曲して いた繊維が弾性力により元に戻ろうとするスプリングバ ックと呼ばれる膨張が起きる. スプリングバックは, 通 常の成形時は成形品の均質性低下を引き起こす問題点と して解釈されるが7), フォームを設計するという視点では 発泡力に相当する. 寸なわち, この CFRTP のスプリング バックを積極活用してフォーム材が創出できると考えた. 加えて, CFRTP の膨張力（スプリングバック力）は炭 素繊維の変形が原動力となるため, 通常の発泡フォーム よりもはるかに大きいと考えられる.これは, 低比重の コアが得られることに加え, 一般に高圧が要求される複 杂倠形状の賦形にも有利に働く可能性が高い.

これらの狙いを実現するには，均質かつ強力なスプリ ングバックを起こさせることが重要となる，そこで，不 連続の炭素繊維を, 面内方向に単繊維レベルで等方・均 質に分散させたマットに, 熱可塑性樹脂を含浸させたシ 一ト状の材料である, 等方性 CFRTP ${ }^{8)-10)}$ の活用を着想した. 本材料のスプリングバック挙動は実験および理論的に検 証されており ${ }^{11)}$ ，スプリングバックの前後の厚さ比（ス プリングバック比） $\mathrm{S}$ は，次式が提案されている.

$\dagger$ 原稿受理 平成 28 年 1 月 13 日 Received Jan.13,2016 @2016 The Society of Materials Science, Japan

* 東レ (株) 複合材料研究所 †791-3193 愛媛県伊予郡

Toray Industries, Inc. Composite Material Research Laboratories. Iyo-gun, Ehime 791-3193. 
ここで，S はスプリングバック比， $a$ は面内方向での単 繊維の配向係数，Iは単繊維のスプリングバック前後の傾 斜比, C は単繊維の接点数を表す. 配向係数 $a$ は, 面外方 向を向く繊維の割合であり，䋊維が Vf100\%で，すべて面 外方向に向いた場合に 1 となる. 傾斜比 I は，スプリング バック前後の繊維の面外方向の傾斜角度の比を表す. 繊 維の接点数 C は，Kallmes によれば，次式で表される ${ }^{12)}$.

$$
C=\frac{8 \lambda}{\pi^{2} D} V f
$$

（ $\lambda$ は繊維長 $(\mathrm{mm}), \mathrm{D}$ は繊維直径(mm)，Vf は䋊維体積 含有率(\%)を表す)

入/D は䋊維のアスペクト比であるから，式(1) および (2)より，纎維のアスペクト比が大きいほど，S が大きく なる．等方性 CFRTP は単繊維レベルで分散したマットに より構成されており，繊維束で構成される通常のマット 材料よりもアスペクト比が大きく， S が大きくなる.

本論文では，等方性 CFRTP を炭素繊維強化フォーム (CFRF: Carbon Fiber Reinforced Foam）ととらえ，そのス プリングバック時の膨張力（スプリングバックカ），フォ 一ム材としての機械特性，および複雑構造を有するサン ドイッチ構造体への応用について検討した.

\section{$2 \mathrm{CFRF}$ 試験試料の作製および評価方法}

\section{$2 \cdot 1$ 炭素繊維マット}

ポリアクリロニトリル（PAN）系炭素繊維（東レ（株） 製 T700SC-12K（引張強度 4900MPa，引張弾性率 230GPa, 比重 $\left.1.8 \mathrm{~g} / \mathrm{cm}^{3}\right)$ ) を䋊維長 $7 \mathrm{~mm}$ に切断し，チョップド䋊維 とした。 得られたチョップド繊維を文献記載の方法 ${ }^{13)}$ より単繊維レベルで等方に分散し， $100 \mathrm{~g} / \mathrm{m}^{2}$ ，厚さ $2.2 \mathrm{~mm}$ の炭素繊維マットを作製した。

\section{$2 \cdot 2$ マトリックス樹脂フィルム}

$2 \cdot 2 \cdot 1 \quad$ ポリプロピレンフィルム ホモポリプロピレン （プライムポリマー (株) 製, 引張強度 $41 \mathrm{MPa}$ ，引張弾 性率 $2 \mathrm{GPa}$ ）と酸変性ポリプロピレン（三井化学（株）製 アドマーQF500, 酸変性度はメーカー非開示) ペレットを 二軸押出機（日本製鋼所（株）製 $\operatorname{TEX} 30 \alpha ， \phi=30$, $\mathrm{L} / \mathrm{D}=31.5$ ）を用いて $210^{\circ} \mathrm{C}, 150 \mathrm{rpm}$, 吐出量 $8 \mathrm{~kg} / \mathrm{hr}$ で混練 し，樹脂ペレットを作製した，得られたペレットを $50^{\circ} \mathrm{C}$ で 3 時間乾燥した後 $20 \mathrm{~g}$ 秤量し, 厚さ $1 \mathrm{~mm}$ のテフロン(登 録商標）シート 2 枚の間に挟んだ。このシートを，油圧 式プレス機の熱盤間に配置し，200 C，0.8MPa で 120 秒間 プレスしたのち， $30^{\circ} \mathrm{C}$ 制御された油圧式プレス機の冷 却盤間に移し，面圧 $0.8 \mathrm{MPa}$ で 60 秒間プレスした。 その 後テフロン（登録商標）シートを除き，厚さ $0.22 \mathrm{~mm}$ $\left(200 \mathrm{~g} / \mathrm{m}^{2}\right)$ の樹脂フィルムを得た。
$2 \cdot 2 \cdot 2$ ポリアミドフィルムポリアミド 6 樹脂（東レ

（株）製，アミラン（登録商標）CM1010）ペレット $20 \mathrm{~g}$ を $80^{\circ} \mathrm{C}$ で 3 時間乾燥させ, ポリプロピレンフィルムの作 製と同様の手順で，厚さ $0.22 \mathrm{~mm}\left(250 \mathrm{~g} / \mathrm{m}^{2}\right)$ の樹脂フィ ルムを得た。このとき，ポリアミドの融点 $\left(225^{\circ} \mathrm{C}\right)$ を考 慮し, 油圧式プレス機の加熱温度を $240^{\circ} \mathrm{C}$ 調整した。

\section{$2 \cdot 3$ 等方性 CFRTP シート}

$300 \mathrm{~mm}$ 角に切断した炭素繊維マットと樹脂フィルムを 2 枚ずつ交互積層し，厚さ $1 \mathrm{~mm}$ のテフロン（登録商標） で挟み，油圧式プレス機の熱盤間に配置した。熱盤の温 度は，ポリプロピレンの場合は $200^{\circ} \mathrm{C}$ ，ポリアミドの場合 は $260^{\circ} \mathrm{C}$ に設定した. 面圧 $4 \mathrm{MPa}$ で 2 分間プレスして樹脂 を含浸させた後, $30^{\circ} \mathrm{C}$ に制御された油圧式プレス機の泠 却盤間に移し，シート温度が $50^{\circ} \mathrm{C}$ となるまで $4 \mathrm{MPa}$ の面 圧で冷却プレスした。テフロン（登録商標）シートを除 き，厚さ $0.55 \mathrm{~mm}$ の等方性 CFRTP シートを得た. 得られ た等方性 CFRTP シートの繊維体積含有率（Vf）は，20\% であった。 なお，油圧プレス機の温度は，使用する樹脂 の融点, 熱分解温度や成形品の厚さを考慮して設定され る. 通常，ポリプロピレン（融点 $160 \sim 165^{\circ} \mathrm{C}$ ）では 180 $\sim 220^{\circ} \mathrm{C}$, ポリアミド 6 (融点 $225^{\circ} \mathrm{C}$ ) の場合は $240 \sim 270^{\circ} \mathrm{C}$ の範囲で設定する.

\section{$2 \cdot 4$ CFRP フォーム材（CFRF）}

以下に, 厚さ $2 \mathrm{~mm}$, スプリングバック比 2.0 の CFRF の作製例を示す。これ以外のスプリングバック比および 厚さについても，材料の投入量とプレス盤面の高さで， 所望の範囲に調節できる.

$2 \cdot 3$ 節で作製した厚さ $0.55 \mathrm{~mm}$ の等方性 CFRP シート 2 枚をテフロン（登録商標）シートで挟み， $200^{\circ} \mathrm{C}$ に設定し た油圧プレス機を用い, 面圧 $3 \mathrm{MPa}$ となるように加圧力を 調整し， 2 分間加圧した．次に，プレス盤面を $2.1 \mathrm{~mm}$ の 高さまで上昇させた（このとき，シートはスプリングバ ックにより，プレス機の天面に接触するまで膨張する).

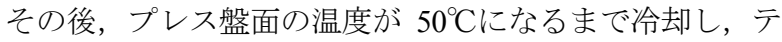
フロン（登録商標）シートを除き，厚さ $2.1 \mathrm{~mm}$ の CFRF を得た．なお，スプリングバック比 1.0 の材料は，プレス 盤面を上昇させず，そのまま冷却することで得た。

スプリングバック比 3.0 の CFRF の外観を Fig. 1 に示す.

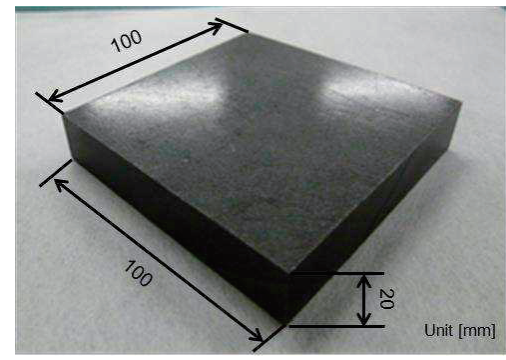

Fig. 1 CFRF (Spring Back Ratio 3.0). 


\section{$2 \cdot 5$ スプリングバックカの測定}

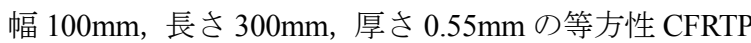
シートを 5 枚積層し（合計厚さ $2.75 \mathrm{~mm}$ ), 遠赤外線ヒー ター（NGK キルンテック（株）製）で，シートの実温が $210^{\circ} \mathrm{C}$ となる条件（設定温度 $270^{\circ} \mathrm{C）で} 1$ 分間加熱してマ トリックス樹脂を溶融させた。このシートを，樹脂が溶 融した状態を維持して圧力センサー付きの金型（設定温 度 $\left.120^{\circ} \mathrm{C}\right)$ 内にすばやく投入し，面圧 $10 \mathrm{MPa}$ にて 1 秒間 プレスしたのち，2・4 節に記載した方法と同様にして，所 望のスプリングバック比になるように金型を上昇させた スプリングバックカは，プレス盤面に配置した圧力セン サー（短手方向 1 箇所，長手方向 6 箇所 (均等配置)）の 最大值とした (試験数は各 1 回)。ここで, 金型温度は脱 型のため樹脂の融点より低くする必要があり, CFRF は冷 却固化に伴い構造が固定されるため, スプリングバック 力は時間とともに低下し，最終的にはゼロになる。

なお，金型温度は成形速度と外観品位のバランスから 選択され，成形品の厚さや形状に応じて調節される。

\section{$2 \cdot 6$ 機械特性の測定}

$2 \cdot 6 \cdot 1$ 曲げ特性 ISO/FDIS 14125 に準じて, 長さ $80 \mathrm{~mm}$, 幅 $10 \mathrm{~mm}$ ，厚さ $4 \mathrm{~mm}$ の試験片を用い，室温下，支点間距 離 $64 \mathrm{~mm}$, 変位速度 $5 \mathrm{~mm} / \mathrm{min}$ の条件で 3 点曲げ試験を行 った (試験数 5 回). 支持点の半径は $2 \mathrm{~mm}$, 圧子の半径 は $5 \mathrm{~mm}$ とした。弾性率は応力-ひず夕線図の初期の直線 部からひずみ $0.2 \%$ 区間を抽出し, 勾配を用いて算出した.

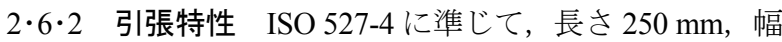
$25 \mathrm{~mm}$ ，厚さ $2 \mathrm{~mm}$ の試験片を用い，室温下，つかみ具間 長さ $150 \mathrm{~mm}$, 変位速度 $2 \mathrm{~mm} / \mathrm{min}$ の条件で試験を行った (試験数 5 回)。なお，変位はクリップゲージにてひずみ を測定し，弾性率は，ひずみ $0.05 〜 0.25 \%$ 範囲の勾配よ り算出した。

$2 \cdot 6 \cdot 3$ 圧縮特性 JIS K7076-A 法に準じて, 長さ 78 mm, 幅 $12.5 \mathrm{~mm}$ ，厚さ $2 \mathrm{~mm}$ の試験片を用い，室温下，変位速 度 $1 \mathrm{~mm} / \mathrm{min}$ の条件で試験を行った (試験数 5 回).なお, タブは同材を用い長さ $35 \mathrm{~mm}$ ，幅 $12.5 \mathrm{~mm}$ ，厚さ $2 \mathrm{~mm}$ の ものを使用し，接着剤で貼付した。弾性率は応力-ひずみ 線図の初期の直線部からひずみ $0.2 \%$ 区間を抽出し，勾配 より算出した.

\section{CFRFのスプリングバックカ}

厚さ $2.75 \mathrm{~mm}$ の等方性 CFRP シートから作製した CFRF のスプリングバック比とスプリングバックカの関係を, Table 1 および Fig. 2 に示す. スプリングバックカはスプ リングバック比の上昇に伴いわずかに低下したが，2MPa 以上という，非常に高い值が保持された。これは，屈曲 していた炭素繊維の復元力を反映しており，通常のフォ 一ムコア（０.3MPa） よりも圧倒的に大きい.
また，スプリングバック比の増加に対してスプリング バック力の低下が小さい。これは屈曲した炭素繊維がバ ネのような挙動を示すことで, 繊維が復元するまでの間 は安定したスプリングバックカを示していると考えてい る. Table 1 に示される範囲内であれば，任意のスプリン グバック比を設定しても，安定した品位の CFRF が得ら れると考えられる。

この均質で強いスプリングバック力は, 炭素繊維が単 繊維レベルで分散し, 多くの接点を持つ（式 (2)のCが大 きい）ことに由来すると考えている.

Table 1 Spring Back Pressure of CFRF.

\begin{tabular}{|c|c|}
\hline Spring Back Ratio & Spring Back Pressure(MPa) \\
\hline 1.8 & 2.5 \\
\hline 2.6 & 2.4 \\
\hline 4.8 & 2.3 \\
\hline 6.1 & 2.3 \\
\hline
\end{tabular}

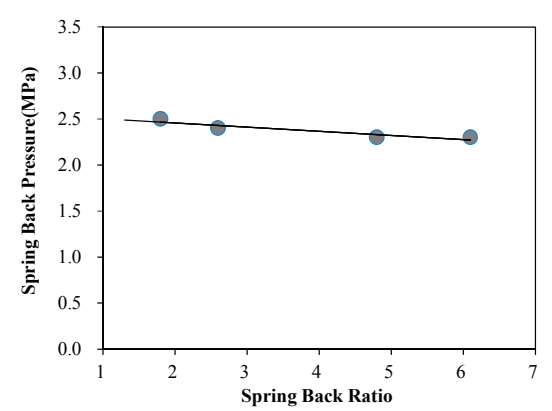

Fig. 2 Relationship between Spring Back Ratio and Spring Back Pressure.

$4 \mathrm{CFRF}$ の機械特性

\section{$4 \cdot 1 \quad$ 曲げ特性}

CFRF のスプリングバック比と曲げ特性の関係を Table 2 に示す. 比較材として, 軽量性に優れる無架橋低 発泡ポリプロピレンシート (Efsel (登録商標) )を用いた。 CFRF は, 発泡ポリプロピレンと同等の比重下で, 10 倍 以上の弾性率を保持し, 軽量化の指標となる比曲げ剛性 に優れることがわかった。

また, スプリングバック比と比曲げ弾性率の関係を Fig. 3 に示す. CFRF の比曲げ弾性率はスプリングバックによ る厚さの増加を受け，線形に近い形で増加した。

Table 2 Bending properties of CFRF.

\begin{tabular}{|c|c|c|c|c|}
\hline & $\begin{array}{c}\text { Spring Back } \\
\text { Ratio }\end{array}$ & $\begin{array}{c}\text { Density } \\
(\mathrm{g} / \mathrm{cm} 3)\end{array}$ & $\begin{array}{c}\text { Modulus } \\
(\mathrm{GPa})\end{array}$ & $\begin{array}{c}\text { Specific Modulus } \\
\left(\sqrt[3]{\mathrm{GPa}} /\left(\mathrm{g} / \mathrm{cm}^{3}\right)\right.\end{array}$ \\
\hline \multirow{3}{*}{ CFRF } & 1.0 & 1.05 & 12.4 & 2.20 \\
\cline { 2 - 5 } & 1.9 & 0.58 & 6.8 & 3.29 \\
\cline { 2 - 5 } & 2.9 & 0.38 & 3.6 & 4.07 \\
\cline { 2 - 5 } & 4.6 & 0.24 & 2.0 & 5.30 \\
\hline Efsel $\otimes$ & 2.0 & 0.48 & 0.4 & 1.54 \\
\cline { 2 - 5 } & 3.0 & 0.33 & 0.2 & 1.77 \\
\hline
\end{tabular}




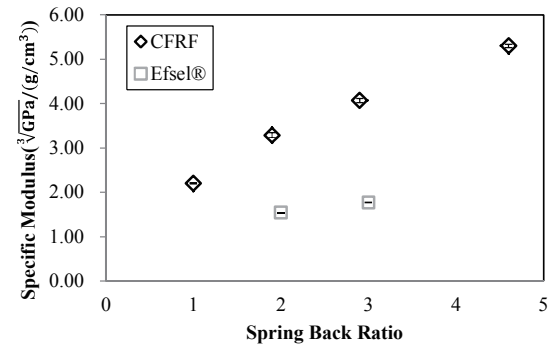

Fig. 3 Relationship between Spring Back Ratio and Specific Modulus.

スプリングバック比 2.9 の CFRF の表面および断面画像 をFig. 4 に示す. 平面図から，面内では炭素繊維が直線を 維持しているのがわかる。これは，炭素繊維が外部から 力を受けない状態では直線形状を取り，自然には屈曲し ないことを意味する。図中の黒い部分は空隙であり, CFRF が樹脂で被覆された炭素繊維で構成されたフォー ムコアという特殊な形態を有することがわかる。なお, 断面写真では切断加工時に樹脂が溶融するため, 繊維の 屈曲有無は確認できなかった。

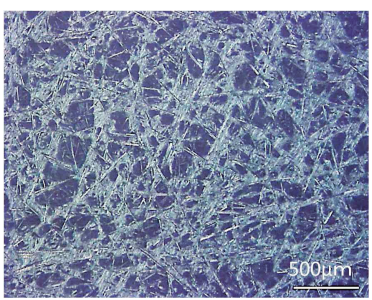

(Ground Image)

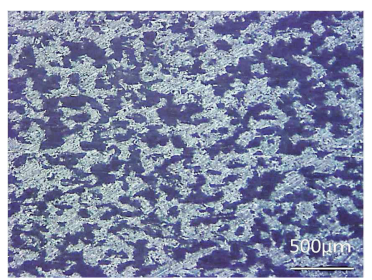

(Cross Section Image)

Fig. 4 Microstructures of CFRF (Spring Back Ratio 2.9).

\section{$4 \cdot 2$ 引張および圧縮特性}

CFRF のスプリングバック比と引張および圧縮弾性率 との関係を，Table 3, 4 および Fig. 5 に示す。引張弾性率 と曲げ弾性率は，スプリングバック比に対してほぼ同様 の挙動を示した。一方，圧縮弾性率はスプリングバック 比の増加に伴う低下幅が小さかった（Fig. 5)。これは， CFRF 中の炭素繊維が単糸状であるため, 圧縮荷重により 屈曲が可能となり，面内方向においてもスプリングバッ ク力が発現し, 圧縮荷重を緩和したためと考えている (Fig. 6）が，試験方法が影響している可能性もあり，詳細の理 解には精査が必要である。

なお，CFRF の圧縮における応力-ひずみ曲線は，線形 に近くなる。これは，圧縮荷重を弾性率の高い炭素繊維 が負担していることを示唆している。

Table 3 Tensile properties of CFRF.

\begin{tabular}{|c|c|c|c|}
\hline $\begin{array}{c}\text { Spring Back } \\
\text { Ratio }\end{array}$ & $\begin{array}{c}\text { Density } \\
(\mathrm{g} / \mathrm{cm} 3)\end{array}$ & $\begin{array}{c}\text { Modulus } \\
(\mathrm{GPa})\end{array}$ & $\begin{array}{c}\mathrm{CV} \\
(\%)\end{array}$ \\
\hline 1.1 & 1.06 & 13 & 4.0 \\
\hline 1.6 & 0.67 & 8.8 & 7.4 \\
\hline 2.1 & 0.51 & 7.2 & 2.2 \\
\hline 3.0 & 0.36 & 4.5 & 7.0 \\
\hline
\end{tabular}

Table 4 Compression properties of CFRF.

\begin{tabular}{|c|c|c|c|}
\hline $\begin{array}{c}\text { Spring Back } \\
\text { Ratio }\end{array}$ & $\begin{array}{c}\text { Density } \\
(\mathrm{g} / \mathrm{cm} 3)\end{array}$ & $\begin{array}{c}\text { Modulus } \\
(\mathrm{GPa})\end{array}$ & $\begin{array}{c}\mathrm{CV} \\
(\%)\end{array}$ \\
\hline 1.0 & 1.01 & 15 & 7.0 \\
\hline 1.6 & 0.69 & 14 & 4.6 \\
\hline 2.1 & 0.53 & 11 & 2.2 \\
\hline 3.1 & 0.35 & 6.6 & 12.9 \\
\hline
\end{tabular}

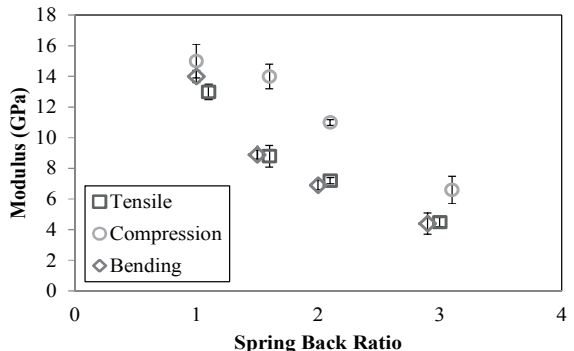

Fig.5 Relationship between Spring Back Ratio and modulus.

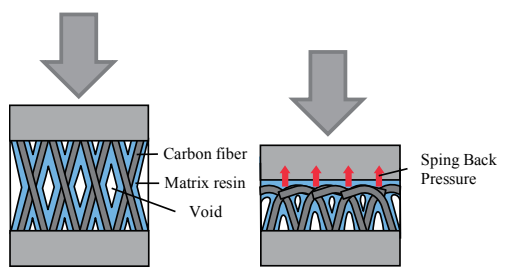

Fig.6 Transformation of the CFRF fiber (compression) .

\section{CFRF の形状賦形}

$5 \cdot 1 \mathrm{CFRF}$ の単独賦形

前節では平板状の試験片の評価から, CFRF が低比重で 優れた弾性率を有することを示した．本項では，もう一 つの狙いである，スプリングバックカを活かした複雑形 状の賦型について検討した。

通常の炭素繊維は伸度が $2 \%$ 以下と低く, プリプレグな どの連続繊維で構成される材料を用いると, 繊維が凹凸 やリブ，絞りなどの形状に追随できない。一方で CFRF を構成する炭素繊維は不連続であり，狭い空間にも充填 できる. 加えて均質で強いスプリングバック力を持つた め, プレス成形で高圧を付与して形状を賦形した後に金 型を上昇させれば，形状を維持しながら膨張すると考え られる，そこで，凹凸面および絞り形状を含むモデル金 型を用い，平板と同様のプロセスで CFRF の形状賦型を 試みた。金型のキャビティ形状を Fig.7 に示す. サイズは 長さ $600 \mathrm{~mm}$, 幅 $300 \mathrm{~mm}$ であり, 左下に直径 $80 \mathrm{~mm}$, 高さ $20 \mathrm{~mm}$ の円形の絞り形状を有する. 右下の矩形凸部は高さ 
20mm で，各部の角は R17 に設計してある。なお，Fig. 7 に示寸破線は，後述する断面観察用の加工ラインである.

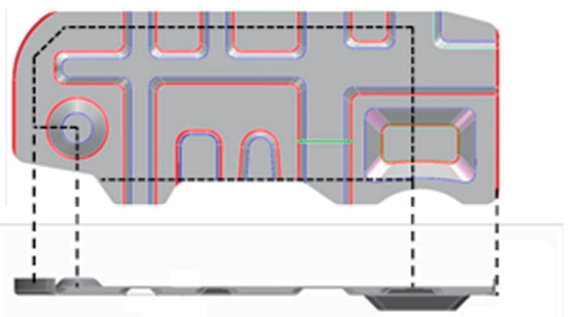

Fig. 7 Detail Drawing of complex shape model part.

本金型を用い，2・4 節に記載のプロセスに従って CFRF の成形を行った。厚さ $0.55 \mathrm{~mm}$ の等方性 CFRTP（ポリプ ロピレンマトリックス) 3 枚を用い，スプリングバック比 3.0 で成形した CFRF 成形品の外観を Fig. 8 に示す. 得ら れた成形品は，凹凸面および絞り形状をよく追随した。 本手法では，原料に板状の等方性 CFRTP のみを用い，特 別なカットパターン形成やプリフォームなど，工程増加 の要因となる作業は行っていない.

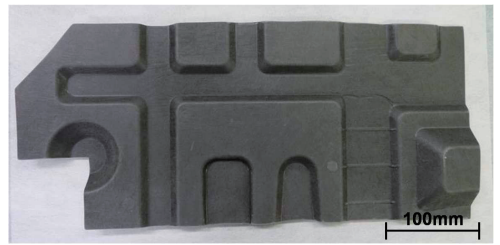

Fig. 8 Molded Product (CFRF) .

Fig.9 に示す 37 点のポイントで測定した成形品の厚さ を Table 5 に示す．変動係数（CV 值）は，1.95\% と非常に 小さく，品位は安定していた。これは等方性 CFRP 中の 炭素繊維が均一に分散されているため, 面外方向に均質 なスプリングバックが生じていることを示している.

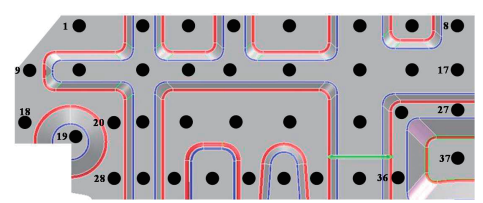

Fig.9 Measurement point of thickness.

Table 5 Thickness of the molding (CFRF) .

\begin{tabular}{|c|c|c|}
\hline Average thickness $(\mathrm{mm})$ & Standard Deviation $(\mathrm{mm})$ & $\mathrm{CV}(\%)$ \\
\hline 5.24 & 0.10 & 1.95 \\
\hline
\end{tabular}

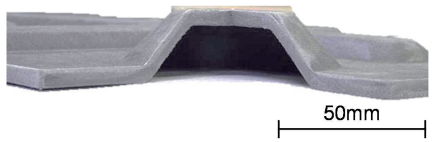

Fig.10 Molded Product of the cross-section (CFRF).

Fig.8 左下の円型絞り形状部分から見た断面図を Fig.10 に示寸．絞り形状の部分も，材料が引きちぎれることな く追随していることがわかる，なお，絞り形状では原料
となる板材よりも表面積が増加するが，これに伴う外表 面の破れやボイドも見られなかった。これは，単繊維が 網面状に存在されていることより（Fig. 4）変形が網の目 が広がるように連続的に起こり，外表面の破れが生じに くいことによる。

\section{$5 \cdot 2$ サンドイッチ構造のワンステップ賦形}

サンドイッチ成形において，スキン層とコア層の接 着・賦型を単一工程で達成できれば大きなメリットとな る. 前項で，フォーム材は単一工程で製造できることが 分かったので, 続いて単一工程で複雑形状を有するサン ドイッチ構造体を賦形する検討を行った。サンドイッチ 構造では，スキン材は剛性に寄与するため空隙を持たな いソリッド構造が求められる。 そこで，スキンに融点の 高いポリアミド 6（融点 $225^{\circ} \mathrm{C}$ ) を用い, 融点差でスキン のみを先に固化させ，コアのみをスプリングバックさせ ることを考えた. 具体的には厚さ $0.55 \mathrm{~mm}$ のポリプロピレ ンをマトリックスとした等方性 CFRTP2 枚（合計厚さ $1.1 \mathrm{~mm})$ を，厚さ $0.55 \mathrm{~mm}$ のポリアミドをマトリックスと した等方性 CFRTP で挟み，これを $2 \cdot 5$ 節の手順に従い成 形した。 その際，ポリアミド 6 を溶融させるために，材 料の実温が $260^{\circ} \mathrm{C}$ とるようにヒーターを調節した. 金型 の温度は $120^{\circ} \mathrm{Cを}$ 維持した。

その結果，表面にポリアミドマトリックスのスキン層 を有し，中心にポリプロピレンマトリックスのコア層を 有した目的の成形品を 1 工程のプレス成形のみで得るこ とに成功した（Fig. 11）。

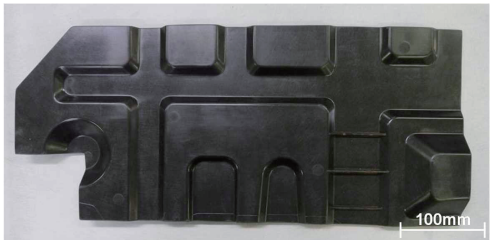

Fig. 11 Molded Product (Sandwich structure).

フォーム成形品と同様に, Fig.9 に示すポイントで測定 したサンドイッチ成形品の厚さを Table 6 に示す. 変動係 数は $3.87 \%$ とフォーム成形品よりもやや高くなったが， 通常の FRP 成形品で見られるバラツキの範囲内であった. この優れた厚み精度は, CFRF の非常に高いスプリングバ ック力が，スキン層を伴った場合でも形状賦形に有効に 作用したことを示唆している.

Table 6 Thickness of the molding (Sandwich structure) .

\begin{tabular}{|c|c|c|}
\hline $\begin{array}{c}\text { Average thickness } \\
(\mathrm{mm})\end{array}$ & $\begin{array}{c}\text { Standard Deviation } \\
(\mathrm{mm})\end{array}$ & $\begin{array}{c}\text { coefficient of variation } \\
(\%)\end{array}$ \\
\hline 4.61 & 0.18 & 3.87 \\
\hline
\end{tabular}

Fig.10 と同じ視点から観察した成形品の断面を Fig.12 に示す。ポリアミドのスキン材部分とポリプロピレンの コア材部分でコントラストが確認された。また，スキン 材とコア材がはく離することもなく，絞り形状部分にも 
よく追随した。スキン材の破れやボイドなどは目視では 確認されず，等方性 CFRTP の変形能力が効果的に働いた ものと考えている

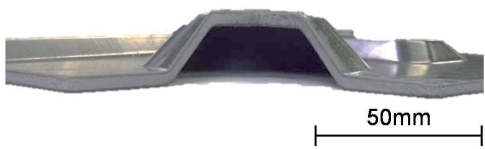

Fig.12 Molded Product of the cross-section (Sandwich).

Fig.13 にスキン層近傍の顕微鏡写真を示す. スキン層に 目立った空隙はなく，コア層は CFRF 平板の構造 (Fig. 4) とよく類似した空隙構造を有していた。 スキン層の厚さ を画像から等間隔に 10 点計測した平均值とばらつきを Table7 に示す．スキン層の厚さは原料厚さと同等だが， 変動係数は $7.07 \%$ と高くなった. これはスキン層とコア層 の境界面で，溶融したマトリックス樹脂が入り組んだ嵌 合構造（アンカリング構造）を形成したためである。こ のアンカリング構造は炭素繊維を巻き込んで形成される ため，強固な接合界面を形成寸る。その結果，本材料で はスキンのはく離が起こりにくい。これは，従来のサン ドイッチ材で必要であった接着工程を不要とし，従来材 料でしばしば問題となっていたスキン材のはく離を根本 的に解決できる可能性がある，今後，接着力の定量化を 進める予定である。

Table7 Thickness of the skin layer.

\begin{tabular}{|c|c|c|}
\hline Average thickness $(\mathrm{mm})$ & Standard Deviation $(\mathrm{mm})$ & $\mathrm{CV}(\%)$ \\
\hline 0.554 & 0.039 & 7.07 \\
\hline
\end{tabular}

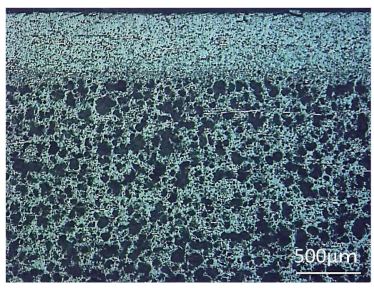

Fig.13 Molded Product (Sandwich structure).

\section{6 結 言}

炭素繊維が単繊維レベルで分散されたマットと熱可 塑性樹脂を使用し，該マットの高いスプリングバック力 を利用することで，軽量性と機械特性に優れたコア材を 創出した。また，本材料は強力なスプリングバックカを 持つため, 金型への追随も良好であり，複雑形状の賦形 が可能であった．さらに，融点の異なる熱可塑性樹脂を 利用することで，凹凸形状を有するサンドイッチ構造体 が，プレス成形のみで得られることを明らかとした。今 後，繊維の分散状態とスプリングバック力の関係や，材 料の面外特性などのデータや，試験手法による特性への 影響についてデータを揃え，フォーム材としてのポテン シャルを定量化する予定である.

本材料は，スキンおよびコアに用いる素材の選択で
様々な特性が発現できると予想され，輸送機器，建材， 筐体などの剛性が要求される部位に幅広く応用可能と 考えている.

本報告の成果の一部は, 国立研究開発法人新エネルギ 一・産業技術総合開発機構（NEDO）の委託事業（「革 新的新構造材料等研究開発」）により得られたものです.

\section{参 考 文 献}

1) C.A. Steeves and N.A. Fleck, "Collapse mechanisms of sandwich beams with composite faces and a foam core, loaded in three-point bending", Part I: analytical models and minimum weight design, International Journal of Mechanical Sciences. Vol.46, No.4, pp.561-583 (2004).

2) Vaikhanski, Lev, and Steven R.Nutt, "Fiber-reinforced composite foam from expandable PVC microspheres.", Composites Part A:Applied Science and Manufacturing. Vol.34, No.12, pp.1245-1253 (2003).

3) A.Desai,M.L.Auad, H.Shen and S.R.Nutt, "Mechanical behavior of hybrid composite phenolic foam." Journal of cellular plastics .Vol.44.No.1, pp.15-36 (2008).

4) Hao Qingxian, Qiu Sawei and Hu Yuebo, "Development on Preparation Technology of Aluminum Foam Sandwich Panels", Rare Metal Materials and Engineering, vol. 44, No.3, pp.548-552(2015).

5) Ning-zhen Wang, Xiang Chen, Ao Li, Yan-xiang Li, Hua-wei Zhang and Yuan Liu, "Three-point bending performance of a new aluminum foam composite structure", Transactions of Nonferrous Metals Society of China, Vol. 26,No.2, pp.359-368 (2016).

6) M.Y.Omara, C.Xianga, N.Gupta, O.M.Strbik III, K. Cho, "Syntactic foam core metal matrix sandwich composite under bending conditions", Materials \& Design, Vol.86, pp.536-544(2015).

7) K. Mizuta, H. Urayama, "Molding method of the FRP molded article" JP.2014-98093(2014).

8) New Energy and Industrial Development Organization, "Development of sustainable hyper composite technology" pp.9-36 (2013).

9) M. Hashimoto, T. Okabe, M. Nishikawa, "Development of Thermoplastic Press Sheet with In-Plane Randomly Oriented and Dispersed Carbon Mono-Fibers and Evaluation of the Mechanical Property", Journal of the Japan Society for Composite Materials, Vol. 37, No.4, pp.138-146 (2011)

10) N.Hirano, A.Tsuchiya, M.Hashimoto, M.Honma and T.Okabe, "Research and Development of the Thermoplastic Stampabullsheet", Journal of the Japan Society for Composite Materials, Vol. 40, No.2, pp.81-86 (2013).

11) Y.Wan,J.Takahashi and I.Ohsawa, "Investigation about the springback effect on short fiber reinforced thermoplastics" , 13th Japan International SMAPE Symposium \& Exhibition, (2013).

12) O.Kallmes and H.Corte, "Structure of paper, I. the statistical geometry of and ideal two dimensional fiber network" , TAPPI, Vol. 43, pp. 737-752 (1960).

13) M.Honma and A.Tsuchiya,"Prepreg and the Preform" JP.2010-235779 (2010). 